\title{
Pengaruh Pelatihan Manajemen Emosi untuk Meningkatkan Regulasi Emosi dan Ekspresi Emosi dalam Konteks Keluarga
}

\author{
Safiruddin Al Baqi \\ Program Studi Pendidikan Agama Islam, Fakultas Tarbiyah, Universitas Darussalam Gontor \\ safiruddinalbaqi@gmail.com \\ Taufik Rizki Sista \\ Program Studi Pendidikan Agama Islam, Fakultas Tarbiyah, Universitas Darussalam Gontor \\ taufikrizki90@gmail.com
}

\begin{abstract}
Abstrak
Regulasi dan ekspresi emosi merupakan kemampuan penting dalam kehidupan sosial manusia. Untuk meningkatkan kedua kemampuan tersebut, lingkungan keluarga adalah lingkungan yang paling tepat. Penelitian ini bertujuan untuk mengetahui efektifitas pelatihan manajemen emosi untuk meningkatkan kemampuan regulasi emosi dan ekspresi emosi yang tepat dalam keluarga. Pelatihan meliputi worksop, mengisi catatan harian emosi keluarga dan menggunakan kartu emosi. Pelatihan diberikan kepada 253 orang tua, namun 82 orang tua yang menyelesaikan hingga akhir program (perempuan = 66; usia rata-rata $38,04)$. Data dikumpulkan pada awal program sebagai baseline dan pre-test dan seletah program sebagai post-test. Regulasi emosi diukur dengan menggunakan Difficulties in Emotion Regulation Scale (DERS16) sedangkan ekspresi emosi menggunakan Measure of Verbally Expressed Emotion (MoVEE). Kedua alat ukur tersebut diadaptasi kedalam bahasa Indonesia dan memiliki kehandalan tinggi. Hasil penelitian menunjukkan bahwa ada perbedaan regulasi emosional diantara peserta sebelum dan sesudah program. Tapi tidak ada perbedaan kemampuan dalam mengekspresikan emosi antara sebelum dan sesudah program.
\end{abstract}

Kata Kunci: ekspresi emosi, manajemen emosi, pelatihan, pelatihan keluarga, regulasi emosi.

\begin{abstract}
Regulation and expression of emotion is important ability in social life. To improve both capabilities, family environment is the most appropriate environment. This study aims to determine the effectiveness of training to improve the emotion regulation and appropriate expression of emotion in the family, filling diary of family emotion and using emotion card. Training was given to 253 parents, and 82 parents completed the program (female $=66$; mean age 38.04). Data was collected at baseline and two weeks later using parent reports. Emotional regulation was measured using Difficulties in Emotion Regulation Scale (DERS-16) whereas emotional expressions used Measure of Verbally Expressed Emotion (MoVEE). Both scales were adapted to Indonesian language and have high reliability. The results showed that there were differences in emotional regulation among participants before and after the program. But there were no difference in the ability to express emotions among participants before and after the program.
\end{abstract}

Keywords: emotion management, emotion regulation, expressions of emotion, parenting skills, training.

Emosi yang dialami setiap individu memiliki pengaruh besar dalam kehidupan sehari-hari mereka, tidak hanya pada diri mereka sendiri tetapi juga pada orang lain di sekitar mereka. Seperti emosi positif bisa mempengaruhi perilaku belanja (Hetharie, 2011). Contoh lain adalah kemarahan seorang supervisor pada tingkat tertentu yang dapat meningkatkan kinerja karyawannya (Lindebaum \& Fielden, 2010), ekspresi positif emosi guru dapat meningkatkan motivasi bagi siswa mereka (Maulana, Opdenakker, Stroet \& Bosker, 2013; Revee, 2016). Disisi lain, ekspresi kemarahan dapat menyebabkan perilaku agresif, baik pada anak-anak (Syahada, 2013) atau remaja dan dewasa (Cautin, Overholser \& Goetz, 2001; Raval, Raval, \& Becker, 2012), serta ekspresi kesedihan dan kemarahan yang dapat berwujud bunuh diri (Widger, 2012).

Sebelum menjadi tingkah laku, emosi diproses terlebih dahulu di setiap individu. Huberty (2012) menjelaskan bahwa suatu stimulus yang menarik perhatian individu akan mengarah pada penilaian kognitif secara langsung mengenai sifat rangsangan tersebut. Selama proses penilaian, kesimpulan segera dicapai mengenai apakah situasinya positif dan menyenangkan, netral atau negatif atau mengancam. Secara hampir bersamaan, emosi dasar atau kompleks diaktifkan, seperti kemarahan, kebahagiaan, atau kesedihan. Emosi yang dialami mengarah pada respons kognitif, perilaku, fisiologis atau kombinasi ketiganya. Respons kognitif mungkin termasuk 
kekhawatiran, kurang menarik perhatian, atau kesulitan konsentrasi. Respons perilaku bisa meliputi agresi, penarikan diri, atau imobilisasi. Respons fisiologis diantaranya meningkatnya denyut jantung, perubahan rona kulit, atau ketegangan otot. Model seperti ini bisa bermanfaat dalam memahami, menilai, dan mengobati masalah regulasi emosi (Huberty, 2012).

Model tersebut menjelaskan bahwa regulasi emosi yang berkaitan dengan kemampuan menilai, mengatur dan mengekspresikan emosi memainkan peran penting dalam kemunculan ekspresi emosional yang tepat. Dan perlu dicatat bahwa ekspresi emosional dapat muncul sebagai komunikasi verbal dan komunikasi nonverbal, seperti ekspresi wajah, gerakan tangan dan gerak tubuh (Prawitasari, 1995). Regulasi emosi dipengaruhi oleh banyak hal, termasuk daerah tempat tinggal (Buntaine \& Costenbader, 1997), kecerdasan emosional (Rivers, Brackett, Katulak, \& Salovey, 2007), budaya (Bear, Zarain, Manning, \& Shiomi, 2009; Osbeck \& Nersessian, 2011; Raval, Raval \& Becker, 2012; Subandi, 2011) dan keluarga (Raval, Raval \& Becker, 2012; Bader, \& Barry, 2014).

Bila seseorang memiliki regulasi emosi yang baik maka akan bisa menghadirkan ekspresi emosi yang tepat, resiliensi (Shanahan, Jones \& Peter, 2011; Power, Cole \& Fredrickson, 2010) dan keterampilan memecahkan masalah (Osbeck \& Nersessian, 2011). Namun, bagi anakanak dan remaja dengan masalah regulasi emosional mungkin mengalami kesulitan dalam memperhatikan situasi dengan benar, menilai secara tepat isyarat, mengidentifikasi dan mengenali emosi yang tepat, atau merespons dengan tepat (Huberty, 2012). Bahkan dalam emosi tertentu seperti kemarahan, dapat menyebabkan gangguan fisik dan psikosomatik (Milers, Rieffe, Terwogt, Cowan \& Linden, 2007; Tarantino, Ranieri, Dionisi, et al., 2013). Jadi sangat penting bagi setiap individu untuk memiliki peraturan emosi yang baik, baik untuk dirinya sendiri atau untuk menjaga hubungan sosial dengan orang-orang di sekitar mereka. Terdapat beberapa bukti yang menunjukkan bahwa regulasi emosi dan kemampuan ekspresi emosi dapat diajarkan, seperti studi yang menunjukkan bahwa pria dan wanita dapat memiliki kontrol kemarahan yang sama meskipun mengungkapkan cara yang berbeda (Kocur \& Deffenbacher, 2014), dan cara ekspresi emosi yang dapat diarahkan melalui cara yang lebih beragam seperti menggunakan sosial media (Lee, 2011).

Keluarga merupakan lingkungan yang sangat strategis untuk mengajarkan keterampilan regulasi emosi dan kemampuan untuk mengekspresikan emosi secara tepat. Penelitian Badder and Barry (2014) menemukan bahwa emosi yang diungkapkan oleh orang tua dalam konteks keluarga mempengaruhi perilaku anak-anak dan remaja dengan autisme dan penelitian Ghanizadeh dan Haghighi (2010) yang mengungkapkan bahwa setting keluarga dan sekolah bisa membantu anak-anak penderita ADHD dalam mengendalikan ekspresi marahnya.

Orangtua memiliki peran penting dalam keluarga untuk mengajarkan perilaku pada anak. Penelitian oleh Ellis, Alisic, Reiss, Dishion \& Fisher (2014) menunjukkan bahwa pembinaan emosi ibu dapat memainkan peran mediasional antara risiko keluarga (yaitu kerugian ekonomi, stres keluarga, dan penganiayaan) dan regulasi emosi pada anak-anak prasekolah. ditambahkan pula bahwa regulasi emosi dapat diajarkan pada anak anak yang mengalami gangguan perilaku (Salmon, Dadds, Allen \& Hawes, 2009; Havighurst, Wilson, Harley, \& Prior, 2009). Bahkan kemampuan mengenali dan mengekspresikan emosi bisa diajarkan pada anak autis (Ryan \& Charragain, 2010).

Hasil studi pendahuluan menunjukkan bahwa permasalah yang dihadapi orang tua siswa diantaranya sulitnya mengekspresikan emosi dihadapan anak mereka. Kesulitan yang dialami dapat dikarenakan kurangnya kemampuan orang tua dalam mengenali emosi apa yang sesungguhnya dirasakan. Kesulitan yang dialami oleh orang tua dalam mengekspresikan emosi dapat berdampak pada anak, baik langsung maupun tidak langsung. Dampak yang paling sederhana adalah bahwa perilaku orang tua dalam mengekspresikan emosi akan ditiru oleh anak, sehingga jika orang tua tidak tepat dalam mengekspresikan emosi anak akan meniru perilaku yang salah. Contoh, orang tua meninggikan volume suara (berteriak) saat marah atau menangis dihadapan anak saat sedih, maka anak akan meniru perilaku orang tua yang dia lihat. Setelah menelaah permasalahan yang ada, maka solusi yang ditawarkan adalah pelatihan peningkatan kemampuan mengelola emosi dan mengekspresikan emosi, utamanya pada orang tua dan diharapkan akan ditiru oleh anak dalam lingkungan keluarga.

Sesuai dengan permasalahan yang disajikan di atas, tujuan dari penelitian ini adalah untuk mengetahui pengaruh pelatihan manajemen emosional untuk meningkatkan kemampuan regulasi emosi dan ekspresi emosi yang sesuai dalam konteks keluarga.

\section{METODE}

\section{Subjek}

Penelitian ini menggunakan pendekatan studi eksperimental dan dilakukan di Ponorogo, Jawa Timur, Indonesia. Pelatihan manajemen emosi diberikan kepada dua kelompok orang tua dan dilaksanakan di setiap sekolah. Secara keseluruhan peneliti membagikan undangan kepada 402 orang tua. Dari jumlah tersebut, hanya 82 orang tua yang mengembalikan pre-test dan post-test secara lengkap, tepat waktu dan dalam prosedur 
yang sesuai. Subjek terdiri dari 66 wanita dan 16 laki-laki dengan rentang usia 27 sampai 60 tahun $($ Mean $=38.04$, $S D=7.13)$.

Tabel 1. Data Deskriptif Subjek

\begin{tabular}{|c|c|c|}
\hline & Frekuensi & Persentase $(\%)$ \\
\hline \multicolumn{3}{|l|}{ Gender } \\
\hline Laki-laki & 16 & 19.5 \\
\hline Perempuan & 66 & 80.5 \\
\hline \multicolumn{3}{|l|}{ Usia } \\
\hline 21-30 & 10 & 12.5 \\
\hline $31-40$ & 47 & 57 \\
\hline $41-50$ & 19 & 23 \\
\hline $51-60$ & 6 & 7.5 \\
\hline Min. & 27 & \\
\hline Maks. & 60 & \\
\hline Mean & 38.04 & $(S D .7 .13)$ \\
\hline \multicolumn{3}{|l|}{ Pendidikan } \\
\hline SD & 7 & 8.5 \\
\hline SMP & 9 & 11 \\
\hline SMA & 33 & 40 \\
\hline Diploma & 2 & 2.5 \\
\hline Sarjana & 20 & 24.5 \\
\hline Pasca-Sarjana & 2 & 2.5 \\
\hline Tidak dijelaskan & 9 & 11 \\
\hline \multicolumn{3}{|c|}{ Jumlah Anggota Keluarga } \\
\hline 3 & 17 & 20.7 \\
\hline 4 & 49 & 59.7 \\
\hline 5 & 11 & 13.4 \\
\hline 6 & 3 & 3.6 \\
\hline 7 & 1 & 1.2 \\
\hline 10 & 1 & 1.2 \\
\hline Mean & 4.1 & (SD. 1.01) \\
\hline $\operatorname{Total}(N)$ & 82 & \\
\hline
\end{tabular}

\section{Instrumen Penelitian}

Difficulties in Emotion Regulation Scale: The DERS-16. Instrumen ini digunakan untuk mengukur tingkat regulasi emosi yang dimiliki orang tua sebelum dan sesudah treatment atau program pelatihan. Versi asli DERS-16 (Bjureberg, at.al., 2016) adalah skala bahasa Inggris, sehingga peneliti menerjemahkannya ke bahasa Indonesia. Setelah di uji coba, maka didapatkan nilai reliabilitas sebesar 0,89 dan semua item dinyatakan valid dengan nilai validitas pada setiap item minimal 0,4. Tidak ditemukan adanya item yang gugur setelah adaptasi DERS-16, sehingga peneliti masih menggunakan 16 item seperti versi asli. Berdasarkan hasil reliabilitas dapat disimpulkan bahwa adaptasi DERS-16 berada pada kategori tinggi.

The Measure of Verbally Expressed Emotion (MoVEE). Instrument ini digunakan untuk mengukur ekspresi emosi yang dimiliki orang tua baik sebelum ataupun sesudah treatment atau program training. The MoVEE (Jacobson, Hill, Pettit \& Miranda, 2015) yang asli merupakan skala yang berbahasa inggris sama halnya dengan DERS-16, sehingga peneliti mengalihbahasakannya kedalam bahasa indonesia. Setelah dilakukan uji coba, maka didapatkan nilai reliabilitas sebesar 0.72. Dari 19 item asli, ditemukan 7 item yang dinyatakan tidak valid sehingga tidak digunakan karena nilai validitas dibawah 0.2.

\section{Prosedur Penelitian}

Penelitian ini dilakukan dalam beberapa tahap, yakni tahap persiapan, pelaksanaan, evaluasi dan analisis data. Berikut adalah rincian tahapan pelaksanaan pelatihan yang telah dilakukan:

Tahap Persiapan. Tahap persiapan diawali dengan melakukan wawancara kepada guru dan kepala sekolah terkait permasalah yang dihadapi pihak sekolah dan orang tua. Dari wawancara yang dilakukan, dapat disimpulkan bahwa orang tua siswa sekolah dasar mengalami kesulitan dalam mengekspresikan emosi dihadapan anak mereka terutama ketika anak mereka mendapatkan nilai yang kurang bagus. Berangkat dari permasalahan yang ada, maka dirumuskan sebuah pelatihan guna memberikaan solusi bagi orang tua dan anggota keluarga yang lain dalam mengelola dan mengekspresikan emosi dengan tepat. Perumusan ini dimulai dengan muembuat modul pelatihan, mengadaptasi alat ukur regulasi emosi dan ekspresi emosi untuk digunakan sebagai alat pretest dan posttest, membuat dan mencetak emotion card, membuat buku diary of family emotion dan membuat powerpoint.

Tahap Pelaksanaan. Tahap pelaksanaan pelatihan dilakukan setelah persiapan selesai dilakukan. Pelaksanaan pelatihan diawali dengan pengenalan macam emosi dan ekspresi emosi, diskusi terkait pengalaman emosi sehari-hari dirumah, relaksasi dan simulasi penggunaan emotion card. Orang tua menjadi kunci penting dalam pelaksanaan hasil latihan ini karena orang tua lah yang mampu memantau dan mengajarka ekspresi emosi yang tepat bagi anak di rumah.

Tahap Evaluasi. Program yang akan dilaksanakan dievaluasi dengan mengadakan follow up terhadap orang tua. Setelah dua minggu menggunakan emotion card dan mengisi diary of family emotion, orang tua diminta mengisi post-test. Selain dari orang tua, indikator keberhasilan program juga dapat diperoleh dari laporan guru terkait perilaku anak disekolah.

Analisis data. Data pre-test dan post-test yang telah dikumpulkan dianalisis dengan menggunakan SPSS 20. Analisis data menggunakan uji $\mathrm{t}$ berpasangan, uji ini digunakan untuk membandingkan dua mean yang berasal dari individu, objek, atau unit terkait yang sama. Dua mean tersebut biasanya mewakili dua waktu yang berbeda (seperti, pre-test dan post-test pada suatu kelompok) atau dua kondisi, namun terkait. Tujuan pengujian ini adalah untuk mengetahui apakah ada bukti statistik yang menunjukkan adanya perbedaan antara data pre-test dan post-test. 


\section{HASIL}

Pengukuran terhadap keadaan awal partisipan dilakukan sebelum dilaksanakan training. Pengukuran awal sekaligus pre-test dilakukan untuk mengetahui kemampuan regulasi emosi, ekspresi emosi, serta data deskriptif partisipan. Pre-test yang disebar sebanyak 402 orang tua, namun yang dapat dianalis (terkait kelengkapan dengan post-test) adalah sebanyak 82. Dari pengumpulan data awal diketahui bahwa partisipan penelitian ini berusia antara 27 hingga 60 tahun, memiliki pendidikan antara pendidikan dasar hingga post-graduate (master degree) dan memiliki anak 1 hingga 8 anak.

Regulasi Emosi. Pengukuran terhadap keterampilan regulasi emosi dilakukan dengan menggunakan Difficulties in Emotion Regulation Scale: The DERS-16. Perhitungan terhadap data pre-test dan post-test subjek dilakukan dengan menggunakan paired sample t-test. Sebelum dilakukan analisis dengan paired sample t-test, dilakukan uji normalitas pada kedua kelompok data. Hasil uji normalitas menunjukkan kedua kelompok data tersebut normal $(.83 / \mathrm{p}>.05$ untuk pre-test dan $.837 / \mathrm{p}>.05$ untuk post-test). Hasil analisis diperoleh nilai signifikansi sebesar $.000(\mathrm{p}<.05)$. hasil ini menunjukkan bahwa hipotesis alternatif diterima yang berarti ada perbedaan antara pretest dan posttest. Hal ini berarti ada peningkatan keterampilan regulasi emosi pada orang tua yang menyelesaikan emotional management training.

Ekspresi Emosi. Pengukuran terhadap ekspresi emosi dilakukan dengan menggunakan The Measure of Verbally Expressed Emotion (MoVEE). Perhitungan terhadap data pre-test dan post-test partisipan dilakukan dengan menggunakan paired sample t-test. Sebelum dilakukan analisis dengan paired sample t-test, dilakukan uji normalitas pada kedua kelompok data. Hasil uji normalitas menunjukkan kedua kelompok data tersebut normal $(.431 / \mathrm{p}>.05$ untuk pre-test dan $.223 / \mathrm{p}>.05$ untuk post-test). Hasil analisis diperoleh nilai signifikansi sebesar .079 ( $\mathrm{p}<.05)$. hasil ini menunjukkan bahwa hipotesis alternatif ditolak yang berarti tidak ada perbedaan antara pretest dan posttest. Hal ini berarti tidak ada perbedaan ekspresi emosi pada orang tua yang menyelesaikan pelatihan manajemen emosi.

\section{PEMBAHASAN}

Pembiasaan dibutuhkan untuk mengekspresikan emosi sekaligus memahami ekspresi emosi orang lain, dan keduanya bisa dilakukan di lingkungan keluarga, yakni lingkungan terdekat seseorang. Nichols, Svetlova, Brownell (2010) dalam penelitiannya menyatakan bahwa anak berusia satu tahun telah mampu membaca ungkapan emosional orang lain meski terbatas pada diferensiasi emosi positif dan negatif. Dan pada usia dua tahun, seorang anak telah bisa membaca ungkapan emosi dasar seperti kesenangan, kesedihan, kemarahan dan ketakutan. Dengan demikian pelatihan untuk mengekspresikan emosi secara tepat dapat dilakukan sejak usia prasekolah.

Untuk membantu sebuah keluarga dalam memahami emosi di antara anggotanya, solusi dalam penelitian ini adalah dengan melatih orang tua dalam keterampilan regulasi emosi dan mengekspresikan emosi. Dalam pelatihan ini digunakan alat yang merupakan buku harian emosi keluarga dan kartu emosi yang terwujud dalam bentuk kartu yang berisi gambar emosi dasar (senang, sedih, takut, marah, malu, cemas, dan merasa bersalah). Gambar pada kartu emosi dipilih dari gambar emosi dari emoticon yang sering ditemukan di ponsel, media sosial (facebook, twitter dan lain-lain). Gambar dipilih karena sederhana namun mampu mewakili emosi yang dirasakan, dan juga sudah biasa dilihat dan digunakan dalam komunikasi elektronik atau media sosial. Setiap anggota keluarga memiliki paket kartu emosional yang terpasang di dinding dan berubah saat ada perubahan emosi. Dan bila ada anggota keluarga lain yang melihat harapan mereka akan berbagi dan mengekspresikan emosi, dan menemukan solusi atas masalah yang dihadapi bersama. Setelah pelatihan selesai, peneliti melakukan pengukuran pada keterampilan regulasi emosi dengan menggunakan The DERS-16. Analisis data pre-test dan post-test menunjukkan peningkatan keterampilan regulasi emosi pada orang tua yang menyelesaikan pelatihan manajemen emosi. Hal ini bisa terjadi karena regulasi emosional melibatkan proses kognisi, sehingga keterampilan bisa berubah dengan adanya pengetahuan baru (Huberty, 2012). Temuan ini konsisten dengan beberapa penelitian lain yang menggunakan pelatihan parenting untuk memperbaiki regulasi emosi. Pelatihan parenting skill bagi orang tua dan anak-anak prasekolah dengan kecenderungan melakukan masalah menunjukkan hasil yang memuaskan, yakni mampu meningkatkan empati, kemampuan yang lebih baik untuk mengenali emosi diri sendiri dan perilaku (Havighurst, Duncombe, Flankling, Holland, Kehoe \& Stargatt, 2015).

Widhiarso dan Prawitasari (2010) menambahkan bahwa kecerdasan emosi, yang berkaitan dengan kemampuan mengenali dan mengekspresikan emosi secara tepat dapat diajarkan kepada anak-anak melalui mata pelajaran di sekolah, seperti subjek agama dan kewarganegaraan. Ini membuktikan bahwa kemampuan regulasi emosional adalah kemampuan yang bisa didapat dari proses belajar, baik dari lingkungan anak maupun dari proses akademik di sekolah.

Di sisi lain, pengukuran ekspresi emosi yang dilakukan dengan menggunakan MoVEE tidak menunjukkan perbedaan pada orang tua yang menyelesaikan pelatihan manajemen emosional. Hasil ini bisa terjadi karena ekspresi emosional adalah keterampilan yang 
membutuhkan pembiasaan dan membutuhkan waktu untuk mengubah kebiasaan.

Penelitian sebelumnya menunjukkan bahwa ekspresi emosional dapat dipengaruhi oleh banyak faktor. Salah satu faktor yang paling berpengaruh adalah budaya. Seperti orang Jawa yang mengajarkan untuk menghindari konflik secara terbuka dengan orang lain. Kemarahan langsung dan terbuka akan dianggap sebagai perilaku tidak sopan yang bisa menimbulkan rasa malu atau isin. Geertz (1961) mengungkapkan bahwa isin adalah salah satu prinsip budaya Jawa yang paling penting yang dimiliki orang Jawa dalam berinteraksi dengan orang lain. Dampak menahan amarah disebut ngempet, membuat situasi subyek dan objek menjadi marah seperti perang dingin, konflik cenderung berlangsung lama dan terlihat baik dari luar. Endraswara (2010) menambahkan budaya semu dalam budaya Jawa. Budaya semu berarti budaya yang menggunakan banyak simbol dalam mengatakan sesuatu. Di dalam banyak ungkapan untuk orang lain. Juga ditemukan bahwa orang Jawa mengekspresikan emosi mereka secara sadar mengikuti etika Jawa (Kurniawan \& Hasanat, 2010).

Studi lain yang berkaitan dengan emosi menunjukkan bahwa ada perbedaan pandangan tentang rasa malu berdasarkan budaya yang dibawa oleh individu. Di kultur barat, anak-anak AS lebih mudah mengekspresikan amarah dan menyulut orang lain, sedangkan sebaliknya dialami anak-anak Jepang. Apa yang terjadi pada anakanak Jepang dipengaruhi oleh pandangan mereka tentang rasa malu dan rasa bersalah berdasarkan tanggung jawab atas perilaku mereka (Bear, Zarain, Manning \& Shiomi, 2009).

Ekspresi emosi juga bisa dipengaruhi oleh peran sosial yang dimiliki individu. Seperti ketika seorang pemimpin menegur kesalahan anggotanya dan ketika orang tua menegur perilaku anak yang tidak pantas. Perilaku asertif yang diangkat terbatas pada ujaran tegas dengan menggunakan teguran melalui kata-kata. Ungkapan kemarahan individu memiliki dampak fisik, psikologis, dan sosial. Seperti saat seseorang menahan emosi terutama emosi negatif, maka efek fisik seperti insomnia dan diare akan muncul. Sedangkan jika diungkapkan, emosi negatif yang dirasakan segera lenyap, bagaimanapun, di budaya timur, ekspresi asertif yang berlebihan juga dapat ditafsirkan sebagai perilaku yang tidak sopan (Al Baqi \& Atamimi, 2016).

Terlepas dari keterbatasan yang ada, temuan penelitian ini memberikan langkah awal yang penting dalam menunjukkan potensi intervensi untuk regulasi emosi keluarga dan ekspresi emosi yang tepat. Dan ada beberapa bukti pendukung terkait dengan hasil penelitian yang menunjukkan keberhasilan program dalam meningkatkan keterampilan regulasi emosional namun tidak dapat memperbaiki ekspresi emosi yang tepat di lingkungan keluarga.

\section{PENUTUP}

Hasil evaluasi dan analisis data menunjukkan bahwa program pelatihan manajemen emosi dapat meningkatkan kemampuan regulasi emosi antar orang tua dalam konteks keluarga, namun program ini tidak mampu meningkatkan kemampuan orang tua untuk mengekspresikan emosi secara tepat dalam konteks keluarga. Hal ini bisa jadi karena regulasi emosi yang terkait dengan proses kognitif yang bisa diubah oleh pengetahuan baru, sedangkan ekspresi emosi adalah perilaku yang membutuhkan waktu untuk menjadi kebiasaan. Meskipun keterbatasan ukuran sampel kecil, follow up yang singkat, dan tingkat putus yang relatif tinggi, temuan ini menunjukkan bahwa, melalui program keterampilan mengasuh anak pada manajemen emosional, orang tua dapat meningkatkan regulasi emosi mereka terhadap keluarga mereka sendiri, dengan implikasi positif untuk regulasi emosi anak mereka dan ekspresi emosi yang tepat.

Dari keterbatasan penelitian ini, peneliti menyarankan penelitian lebih lanjut dengan tema serupa. Menciptakan sebuah pelatihan yang benar-benar tepat untuk meningkatkan kemampuan regulasi emosi dan ekspresi emosi yang tepat.

\section{Ucapan Terima Kasih}

Peneliti mengucapkan banyak terima kasih kepada Lembaga Penelitian dan Pemberdayaan Masyarakat (LPPM) Universitas Darussalam Gontor dan Fakultas Tarbiyah Universitas Darussalam Gontor yang telah mendukung penelitian ini sejak awal, baik moral maupun finansial. Peneliti juga berterima kasih kepada Dr. Imam Bahroni, M.A., M.Ls., Agus Budiman, M.Pd., dan Dr. Muhammad Fajar Pramono, M.Si. yang telah menuntun peneliti selama program ini, serta kepada Muhammad Abdul Basit, Gatot Handoko, Yudha Rouf, Deni Anggrayani dan Antos Riyadi, M.A. yang telah membantu mengumpulkan data dan analisis data.

\section{DAFTAR PUSTAKA}

Al Baqi, S. \& Atamimi, N. (2016). Strategi pengelolaan marah dan ekspresi emosi marah pada orang Jawa In Himawan, K. K., Pratiwi, I. W., et. al. (Eds) Prosiding Seminar Nasional \& Call For Paper: Psikologi Indigenous Indonesia 2016: Kebhinekaan dan Masa Depan Indonesia: Peran Ilmu Sosial dalam Masyarakat, 27 Agustus 2016. Malang, Indonesia: Fakultas Pendidikan Psikologi Universitas Negeri Malang.

Bader, S. H. \& Barry T.D. (2014). A longitudinal examination of the relation between parental 
expressed emotion and externalizing behaviors in children and adolescents with autism spectrum disorder. Journal of Autism and Developmental Disorders, 44, 2820-2831.

Bear, G. G., Zarain, X. U., Manning, M. A., \& Shiomi, K. (2009). Shame, guilt, blaming, and anger: differences between children in Japan and the US. Motivation and Emotion, 33, 229-238.

Bjureberg, J., Ljotsson, B., Tull, M.T., Hedman, E., Sahlin, H., Lundh, L., et. al. (2016). Development and validation of a brief version of the difficulties in emotion regulation scale: The DERS-16. Journal of Psychopathology and Behavioral Assessment, 38, 284-296.

Buntaine, R. L., \& Costenbader, V. K. (1997). Selfreported differences in the experience and expressionof anger between girls and boys. Sex Roles, $36,625-637$.

Cautin, R. L., Overholser, J. C.,\& Goetz, P. (2001). Assesment of mode of anger expression in adolescent psychiatric inpatients. Adolescence, 36(141), 163170.

Ellis, B.H., Alisic, E., Reiss, A., Dishion, T. \& Fisher, P.A. (2014). Emotion regulation among preschoolers on a continuum of risk: the role of maternal emotion coaching. Journal of Child and Family Studies, 23, 964-974.

Endraswara, S. (2010). Etika Hidup Orang Jawa: Pedoman Beretika dalam Menjalani Kehidupan Sehari-hari. Yogyakarta: Penerbit Narasi.

Gasser, L., Gutzwiller-Helfenfinger, E., Latzko, B. \& Malti, T. (2013). Moral emotion attributions and moral motivation dalam K. Heinrichs, F. Oser \& T. Lovat (Eds.), Handbook of Moral Motivation: Theories, Models, Applications, (pp. 307-322). Rotterdam: Sense Publishers.

Ghanizadeh, A., \& Haghighi, H. B. (2010). How do ADHD children perceive their cognitive, affective, and behavioral aspects of anger expression in school setting?. Child and Adolescent Psychiatry and Mental Health, 4(4), 1-7.

Geertz, H. (1961). The Javanes Family: A Study of Kinship and Socialization. USA: The Free Press of Glencoe.

Havighurst, S.S., Wilson, K.R., Harley, A.E. \& Prior, M.R. (2009). Tuning in to kids: an emotion-focused parenting program-initial findings from a community trial. Journal of Community Psychology, 37(8), 1008-1023.

Hetharie, J.A. (2011). Peran emosi positif sebagai mediator stimulus lingkungan toko dan faktor sosial terhadap impulse buying tendency pada Matahari Departement Store Kota Ambon. Jurnal Aplikasi Manajemen, 10(4), 890-898.
Huberty, T.J. (2012). Anxiety and depression in children and adolescents: assessment, intervention, and prevention. Bloomington: Springer Science \& Business Media.

Jacobson, C., Hill, R.M., Pettit, J.W. \& Miranda, R. (2015). The measure of verbally expressed emotion: development and factor structure of a scale designed to assess comfort expressing feelings to others. Journal of Psychopathology and Behavioral Assessment, 37, 358-369.

Kurniawan, A. P.,\& Hasanat, N. U. (2010). Ekspresi emosi pada tiga tingkatan perkembangan pada suku Jawa di Yogyakarta: Kajian psikologi emosi dan kultur pada masyarakat Jawa. Jurnal Psikologi Indonesia, 7(1), 50-64.

Kocur, J. L., \& Deffenbacher, J. L. (2014). Anger and anger's expression generally and in romantic relationships. Contemporary Family Therapy, 36, 120-134.

Lee, C. S. (2011). Exploring emotional expressions on YouTube through the lens of media system dependency theory. New Media \& Society, 14(3), 457-475.

Lindebaum, D., \& Fielden, S. (2010). 'It's Good to be angry': enacting Anger in construction project management to achieve perceived leader effectiveness. Human Relation, 64(3), 437-458.

Maulana, R., Opdenakker, M-C., Stroet, K. \& Bosker, R. (2013). Changes in teachers' involvement versus rejection and links with academic motivation during the first year of secondary education: A multilevel growth curve analysis. Journal of Youth and Adolescence, 42, 1348-1371.

Milers, A. C., Rieffe, C., Terwogt, M. M., Cowan, R., \& Linden, W. (2007). The Relation between anger coping strategies, anger mood and somatic complaints in children and adolescents. Journal of Abnormal Child Psychology, 35, 653-664.

Nichols, S., Svetlova, M. \& Brownell, C.A. (2010). Toddlers' Prosocial Behavior: From Instrumental to Empathic to Altruistic Helping. Child Development, 81(6): 1814-1827.

Osbeck, L. M. \& Nersessian, N. J. (2011). Affective problem solving: emotion in research practice. Mind and Sociaty, 10, 57-78.

Power, C. A., Cole, E. R., \& Fredrickson, B. L. (2010). Poor women and the expression of shame and anger: the price of breaking social class feeling rules. Feminism and Psychology, 21(2), 179-197.

Prawitasari, J. E. (1995). Mengenal emosi melalui komunikasi nonverbal. Buletin Psikologi, 3(1), 27-43.

Raval, P. P., Raval, P. H., \& Becker, S. P. (2012). “He cursed, and I got angry:' Beliefs about anger among 
adolescent male offenders in India. Journal of Child and Family Studies, 21, 320-330.

Reeve, J. (2016). A Grand theory of motivation: why not?. Journal of Motivation and Emotion, 40, 31-35.

Rivers, S. E., Brackett, M. A., Katulak, N. A., \& Salovey, P. (2007). Regulating anger and sadness: An exploration of discrete emotions in emotion regulation. Journal of Happiness Studies, 8, 393-427.

Ryan, C. \& Charragain, C. N. (2010). Teaching emotion recognition skills to children with autism. Journal of Autism and Developmental Disorders, 40, 1505-1511.

Salmon, K., Dadds, M.R., Allen, J. \& Hawes, D.J. (2009). Can emotional language skills be taught during parent training for conduct problem children?. Child Psychiatry and Human Development Journal, 40, 485-498.

Shanahan, S., Jones, J., \& Peter, B. T. (2011). Are you looking at me, or am I? Anger, aggression, shame and self-worth in violent individuals. Journal of RationalEmotive and Cognitive-Behavior Therapy, 29, 71-91.

Syahada, Y. M. (2013). Pelatihan regulasi emosi untuk menurunkan perilaku agresif pada Anak. Humanitas, 10(1), 19-36.

Subandi. (2011). Family expressed emotion in a Javanese cultural context. Culture and Medical Psychiatry, 35, 331-346.

Tarantino, S., Ranieri, C. D., Dionisi, C., Citti, M., Capuano, A., Galli, F, Guidetti, V., Vigevano, F., Gentile, S., Presaghi, F., \& Valeriani, M. (2013). Clinical features, anger management and anxiety: a possible correlation in migraine children. The Journal of Headache and Pain, 14(39), 1-8.

Widhiarso, W., \& Prawitasari, J. E. (2010). Struktur semantik kata emosi dalam Bahasa Indonesia. Jurnal Psikologi, 37(2), 153-164.

Widger, T. (2012). Suffering, frustration, and anger: class, gender and history in Sri Lankan suicide Stories. Culture and Medical Psychiatry, 36, 225-244.

Widuri, E. L. (2012). Regulasi emosi dan resiliensi pada mahasiswa tahun pertama. Humanitas, 9(2), 147-156.

\section{LAMPIRAN}

Gambar 1. Buku Diary of Family Emotion
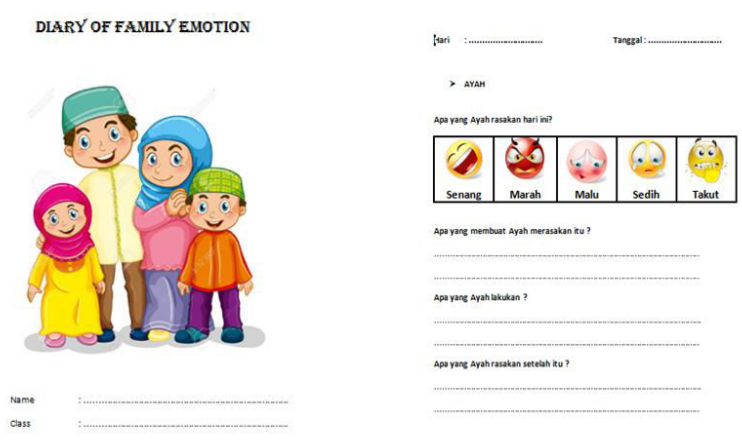

Gambar 2. Emotion Card

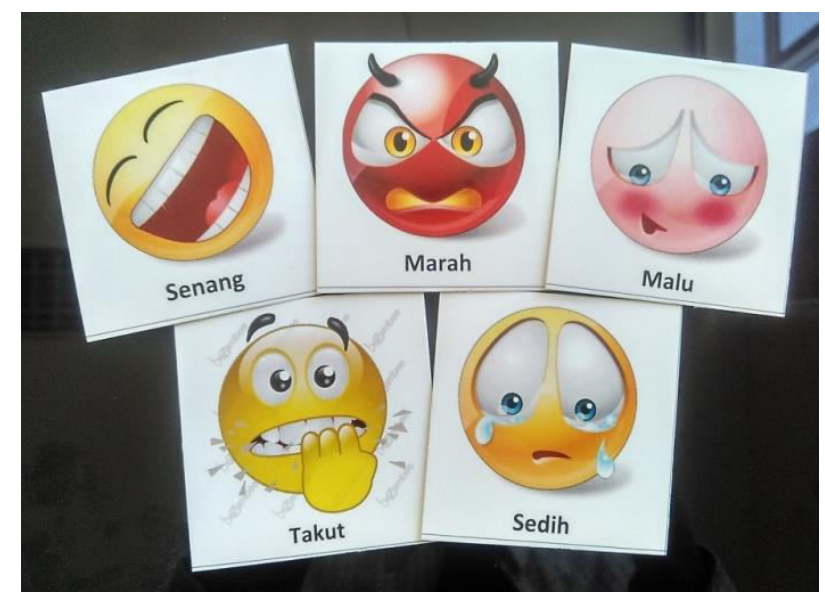

